\title{
Investigation into the effects of fuel composition on the emission characteristics of a low-speed direct injection engine
}

\author{
K. B. K. Ibrahim ${ }^{1} \&$ I. A. Rufai ${ }^{2}$ \\ ${ }^{1}$ Ministry of Foreign Affairs, Nigeria \\ ${ }^{2}$ Mechanical Engineering Department, Bayero University Kano, Nigeria
}

\begin{abstract}
This paper presents the results of an investigation into the effect of fuel composition on the emission characteristics of a four stroke, single cylinder, Viking super direct injection diesel engine run at different operating conditions using diesel fuel and soybean biodiesel blends (B15, B20 and B25). A PerkinElmer 2400 series $\mathrm{CHNS} / \mathrm{O}$ elemental analyser was used in determining the fuel composition. Exhaust emission testing was conducted using Crowcon gas sensors to quantify the concentration of Nitrogen dioxide (NO2), carbon monoxide (CO) and sulphur dioxide (SO2) from the exhaust gases. The relationships between the exhaust emissions, engine speed, torque, throttle position and elemental fuel composition have been reported. The predictive model equations were developed using multiple regression analysis to predict exhaust emissions. The results show that the engine that is run on B15 gives the lowest levels of Nitrogen dioxide (NO2) emissions of $2.58 \mathrm{ppm}$, carbon monoxide (CO) emissions of $0.153 \mathrm{ppm}$ and sulphur dioxide (SO2) emissions of $6.5 \mathrm{ppm}$ when compared to other fuel blends. This outcome signals the possibility of using B15 as an alternative fuel to diesel for a healthier environment.

Keywords: fuel composition, soya biodiesel, emissions, environmental pollution.
\end{abstract}

\section{Introduction}

The idea of using vegetable oils instead of diesel fuel is not new and goes back to at least 1928 [1]. Since then, the concept was dropped due to the cheap supply of petroleum-based fuels. The environmental concern and depletion of 
conventional sources have prompted research world-wide into alternative energy sources for internal combustion (IC) engines. Biofuels appear to be a potential alternative energy resource to fossil fuels because it is renewable and available throughout the world. The sulphur content is negligibly small thus the issue of acid rain is ameliorated. The problem of using neat vegetable oils in diesel engines relates to their high viscosity. Today, diesel engines are a major and widely used power source for in-sea and on-land transportation vehicles due to their simple mechanism, excellent performance, easy maintenance, low fuel oil cost, low fuel consumption rate, low breakdown rate, high compression ratio, high power/weight ratio, high fuel oil density, high thermal efficiency and durability. However, diesel engines are also considered a major source of air pollution in port and urban areas because of their black smoke, HC, NOx, particulate matter (PM), $\mathrm{CO}, \mathrm{CO}_{2}, \mathrm{SOx}$ emissions. The disgusting odor and noise from these engines may impair human health and the natural environment, such as ozone layer destruction, greenhouse effect enhancement and acid rain production [2-4]). While diesel engines are still the most common energy production equipment for ships, the air pollution threat caused by them cannot be neglected.

Studies show that the composition of diesel exhaust gas varies considerably, depending on the engine type, operating conditions, fuel, lubricating oil, and whether an emission control system is present. Reduction of exhaust emissions is extremely important for diesel engine development in view of increasing concern regarding environmental protection and stringent exhaust gas regulations. Controlling diesel exhaust emissions through fuel modification seems to be promising because it would affect both the new and old engines. The modification of diesel fuel to reduce exhaust emissions can be performed by increasing the cetane number, reducing fuel sulphur, reducing aromatic content, increasing fuel volatility and decreasing the fuel density. However, the potential of conventional diesel fuel for emissions reduction has already been, to a large extent, exploited and the most important fuel parameters mentioned above can nowadays be changed within only a narrow range.

\section{Materials and methods}

\subsection{Experimental set-up for the determination of fuel composition}

The instrumentation used in this study includes a PerkinElmer 2400 Series II CHNS/O Analyzer and a PerkinElmer AD6 microbalance. Both the analyzer and the microbalance were connected to a Windows based PC running Perkin Elmer's proprietary software.

\subsection{Engine set-up}

A single cylinder Viking Super diesel engine was used as the test engine. It is an air-cooled direct injection, four-stroke, horizontal type engine. The engine specifications are given in Table 1. 
Table 1: Test engine specifications.

\begin{tabular}{|c|l|l|}
\hline S/No. & \multicolumn{1}{|c|}{ Description } & \multicolumn{1}{c|}{ Specification } \\
\hline 1. & Engine Model & $165 \mathrm{~F}$ \\
\hline 2. & Type & $\begin{array}{l}\text { Horizontal Single Cylinder four stroke, air } \\
\text { cooled }\end{array}$ \\
\hline 3. & Bore/Stroke & $65 / 70 \mathrm{~mm}$ \\
\hline 4. & Compression Ratio & $20.5-22$ \\
\hline 5. & Max. Torque & $8.9 \mathrm{Nm}$ \\
\hline 6. & Max. Brake Power & $2.43 \mathrm{~kW}$ \\
\hline 7. & Rated Speed & $2600 \mathrm{rpm}$ \\
\hline 8. & Fuel Injection Pressure & $14 \mathrm{MPa}$ \\
\hline 9. & Injection opening angle & $20^{\circ}-24^{\circ}$ before T.D.C \\
\hline
\end{tabular}

The engine was mounted on a test bench and then connected to a hydraulic dynamometer and control panel, which has accessories for monitoring speed, torque and temperature. The fuel sample was fed from fuel tank mounted on the instrumentation unit and was being gravity fed to the engine, which was below the level of the tank. The engine tests were conducted at three different throttle positions (I - fully opened, II - three-quarter opened and III - half opened). Under each of the positions, the engine speed was kept constant while the load was varied and the corresponding exhaust gases recorded. The procedure was repeated with the load kept constant and engine speed varied for diesel fuel and blends. All readings were taken after stable operating conditions were experimentally achieved. Figure 1 shows the experimental set up.

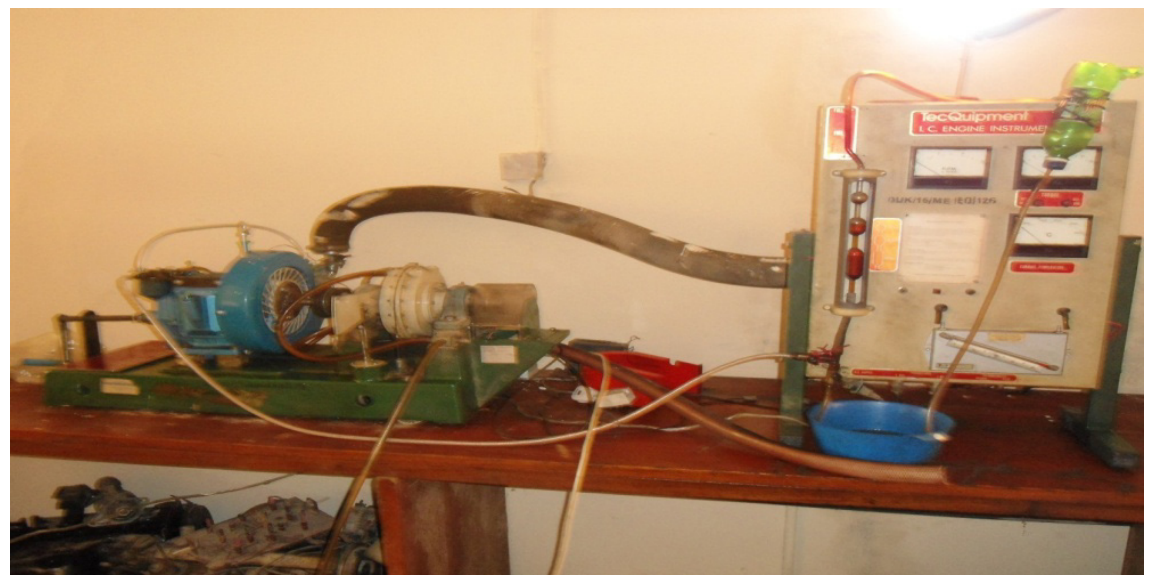

Figure 1: $\quad$ Engine set up with control panel. 
The parameters recorded at each operating condition include: engine speed (rpm); torque $(\mathrm{Nm})$; exhaust temperature $\left({ }^{\circ} \mathrm{C}\right) ; \mathrm{NO}_{2}$ emission (ppm); $\mathrm{CO}$ emission (ppm) and $\mathrm{SO}_{2}$ emission (ppm). The compositions of the exhaust toxic gases were measured using the Crowcon gas sensor obtained from the Pollution Control Laboratory, Ministry of Environment, Kano, Nigeria.

The data obtained were further analysed using statistical method of regression analysis. It is imperative to note that, the exhaust gas emission of $\mathrm{NO}_{2}, \mathrm{CO}$ and $\mathrm{SO}_{2}$ are functions of the engine speed, torque, throttle position and blend ratio as shown in the following equations:

$$
\left\{\begin{array}{c}
\mathrm{NO}_{2} \\
\mathrm{CO} \\
\mathrm{SO}_{2}
\end{array}\right\}=F(n, T, Z, R)
$$

where: $n$ is the engine speed in rpm, $T$ is the torque in Nm, $Z$ is the throttle position and $R$ is the blend ratio.

Similarly, the exhaust gas emissions of $\mathrm{NO}_{2}, \mathrm{CO}$ and $\mathrm{SO}_{2}$ may be expressed as functions of the elemental fuel composition as shown in the equation below:

$$
\left\{\begin{array}{l}
\mathrm{NO}_{2} \\
\mathrm{CO} \\
\mathrm{SO}_{2}
\end{array}\right\}=F(C, H, O, S)
$$

where: $C$ is the carbon, $H$ is the hydrogen, $O$ is the oxygen and $S$ is the sulphur compositions in the fuel.

For this study, it was assumed that the relation between the emissions and the other independent variable is linear and could be studied using linear regression techniques. However, it should be noted that the word "linear" in linear regression does not mean that the function is a straight line, but that the partial derivatives with respect to each coefficient are not functions of other coefficients [5]. Therefore, equations 1 and 2 may be transformed to the model equations 3 and 4 respectively in the form:

$$
\begin{aligned}
& \left.\left\{\begin{array}{c}
\mathrm{NO}_{2} \\
\mathrm{CO} \\
\mathrm{SO}_{2}
\end{array}\right\}=A+B n+C T+D Z+E R\right) \\
& \left.\left\{\begin{array}{c}
\mathrm{NO}_{2} \\
\mathrm{CO} \\
\mathrm{SO}_{2}
\end{array}\right\}=a+b C+c H+d O+e S\right)
\end{aligned}
$$

where: $A, B, C, D, E, a, b, c, d$ and $e$ are constants obtained from the regression analysis.

In reality, engine emission may be influenced by both operating settings and fuel composition. Therefore, equations 3 and 4 may be represented in the form: 


$$
\left\{\begin{array}{c}
\mathrm{NO}_{2} \\
\mathrm{CO} \\
\mathrm{SO}_{2}
\end{array}\right\}=\mathcal{F}(C, H, O, S, n, T, Z, R)
$$

It can be noted that when $n, T, Z, R=$ constant (fixed) equation 5 becomes equation 2; while as $C, H, O, S=$ Constant, equation 5 becomes equation 1 . Thus, emission of any of the gases may then be expressed in matrix form as:

$$
\left[\begin{array}{c}
\mathrm{NO}_{2} \\
\mathrm{CO}_{2}
\end{array}\right]=a+b C+c H+\delta O+e S+f n+g T+h Z+i R
$$

Three generalized model equations were determined from the regression analysis of the exhaust gas emissions taking cognizance of engine speed, torque, throttle position and elemental compositions of the fuel. The regression analysis indicates that the generalized equations show better correlation with respect to the parameters considered in that, the value of any emission can be predicted in as much as the other independent variables are known.

\section{Results and discussion}

The test analyzer used in the elemental analysis is usually employed for the determination of carbon and hydrogen content of liquid fuels including gasoline, diesel, biodiesel blends, and gasoline-ethanol blends. When the only elements present in significant quantities are carbon and hydrogen, the oxygen content can be determined by difference. Tables 2 and 3 show the elemental composition and properties respectively of fuel blends used for the study.

Table 2: Elemental composition in fraction of fuel used.

\begin{tabular}{|c|c|c|c|c|c|}
\hline \multirow{2}{*}{ Elements } & \multicolumn{5}{|c|}{ Fuel Blends } \\
\cline { 2 - 6 } & $\mathrm{B}_{0}$ & $\mathrm{~B}_{15}$ & $\mathrm{~B}_{20}$ & $\mathrm{~B}_{25}$ & $\mathrm{~B}_{100}$ \\
\hline $\mathrm{C}$ & 0.8520 & 0.8490 & 0.8412 & 0.8310 & 0.7607 \\
\hline $\mathrm{H}$ & 0.1240 & 0.1230 & 0.1220 & 0.1210 & 0.1181 \\
\hline $\mathrm{O}$ & 0.0040 & 0.0269 & 0.0355 & 0.0465 & 0.1162 \\
\hline $\mathrm{S}$ & 0.0200 & 0.0011 & 0.0013 & 0.0015 & 0.0050 \\
\hline
\end{tabular}

Table 3: Properties of diesel and biodiesel produced from soybeans oil.

\begin{tabular}{|l|c|c|c|c|c|}
\hline \multicolumn{1}{|c|}{ Property } & Diesel & $\mathrm{B}_{15}$ & $\mathrm{~B}_{20}$ & $\mathrm{~B}_{25}$ & $\mathrm{~B}_{100}$ \\
\hline Density at $15^{\circ} \mathrm{C}\left(\mathrm{kg} / \mathrm{m}^{3}\right)$ & 830 & 836 & 842 & 849 & 878 \\
\hline Flash Point $\left({ }^{\circ} \mathrm{C}\right)$ & 66 & 78 & 84 & 86 & 97 \\
\hline Viscosity at $40^{\circ} \mathrm{C}(\mathrm{cSt})$ & 6.5 & 7.1 & 7.6 & 8.0 & 10.2 \\
\hline Calorific Value $(\mathrm{MJ} / \mathrm{kg})$ & 44 & 43.9 & 43.95 & 43.85 & 43.6 \\
\hline Cetane Number & 47 & 47.42 & 47.79 & 48.21 & 50.4 \\
\hline
\end{tabular}


Experimental results show that the $\mathrm{NO}_{2}$ emission for diesel and all the blends followed an increasing trend with respect to load for all throttle positions (position I - fully opened, position II - three-quarter opened and position III - half opened) as shown in Tables 4, 5 and 6. In a similar way, the emissions of the test engine, run on B25 biodiesel were investigated (not shown). For the blends, an increase in the emission was found at all loads when compared to diesel (Tables 5 and 6). While from the variation of nitrogen dioxide with engine speed (speed characteristics), it was observed that, the $\mathrm{NO}_{2}$ emission for diesel is much lower than that of the blends at all speeds. Also the $\mathrm{NO}_{2}$ emission for diesel and all the blends followed a decreasing trend with respect to increase in speed at all the levels of the throttle positions. Similar observations for carbon

Table 4: Exhaust gas emissions for engine run on Diesel (B0).

A) At throttle position I (fully opened).

\begin{tabular}{|c|c|c|c|c|c|c|}
\hline \multirow{2}{*}{$\mathrm{S} / \mathrm{No}$} & \multirow{2}{*}{$\begin{array}{c}\text { SPEED } \\
(\mathrm{rpm})\end{array}$} & \multirow{2}{*}{$\begin{array}{c}\text { TORQUE } \\
(\mathrm{Nm})\end{array}$} & \multirow{2}{*}{$\begin{array}{c}\text { EXHAUST } \\
\text { TEMP. }\end{array}$} & \multicolumn{3}{|c}{$\begin{array}{c}\text { COMPOSITION OF EXHAUST } \\
\text { TOXIC GASES (ppm) }\end{array}$} \\
\cline { 5 - 7 } & & & $\mathrm{CO}$ & $\mathrm{NO}_{2}$ & $\mathrm{SO}_{2}$ \\
\hline 1 & 2600 & 0.8 & 132 & 10 & 1.3 & 24 \\
\hline 2 & 2600 & 1.8 & 153 & 9.4 & 1.4 & 23 \\
\hline 3 & 2600 & 2.7 & 171 & 8.7 & 1.5 & 22 \\
\hline 4 & 2600 & 3.6 & 198 & 7.2 & 2.1 & 15 \\
\hline 5 & 2600 & 4.8 & 219 & 7.0 & 2.3 & 11 \\
\hline
\end{tabular}

B) At Throttle position II (three-quarter opened).

\begin{tabular}{|c|c|c|c|c|c|c|}
\hline & \multirow{2}{*}{$\mathrm{S} / \mathrm{No}$} & \multirow{2}{*}{$\begin{array}{c}\text { SPEED } \\
(\mathrm{rpm})\end{array}$} & \multirow{2}{*}{$\begin{array}{c}\text { TORQUE } \\
(\mathrm{Nm})\end{array}$} & \multirow{2}{*}{$\begin{array}{c}\text { EXHAUST } \\
\text { TEMP. }{ }^{\circ} \mathrm{C}\end{array}$} & \multicolumn{3}{|c|}{\begin{tabular}{c} 
COMPOSITION OF EXHAUST \\
\cline { 4 - 7 }
\end{tabular}} & & $\mathrm{CO}$ & $\mathrm{NO}_{2}$ & $\mathrm{SO}_{2}$ \\
\hline 1 & 1900 & 0.8 & 120 & 6.8 & 1.4 & 23.5 \\
\hline 2 & 1900 & 1.0 & 128 & 6.2 & 1.6 & 23.1 \\
\hline 3 & 1900 & 2.0 & 142 & 4.2 & 2.2 & 22.5 \\
\hline 4 & 1900 & 2.5 & 165 & 3.0 & 2.7 & 22.3 \\
\hline 5 & 1900 & 3.2 & 190 & 2.3 & 3.1 & 22.0 \\
\hline
\end{tabular}

C) At throttle position III (Half opened).

\begin{tabular}{|c|c|c|c|c|c|c|}
\hline \multirow{2}{*}{$\mathrm{S} / \mathrm{No}$} & \multirow{2}{*}{$\begin{array}{c}\text { SPEED } \\
(\mathrm{rpm})\end{array}$} & \multirow{2}{*}{$\begin{array}{c}\text { TORQUE } \\
(\mathrm{Nm})\end{array}$} & \multirow{2}{*}{$\begin{array}{c}\text { EXHAUST } \\
\text { TEMP. }{ }^{\circ} \mathrm{C}\end{array}$} & \multicolumn{2}{|c|}{$\begin{array}{c}\text { COMPOSITION OF EXHAUST } \\
\text { TOXIC GASES (ppm) }\end{array}$} \\
\hline 1 & 1200 & 0.8 & 110 & 5.1 & 2.0 & 23.1 \\
\hline 2 & 1200 & 1.2 & 121 & 4.8 & 2.4 & 22.8 \\
\hline 3 & 1200 & 1.8 & 133 & 4.2 & 2.8 & 22.4 \\
\hline 4 & 1200 & 2.4 & 156 & 3.8 & 3.2 & 22.1 \\
\hline 5 & 1200 & 3.0 & 171 & 2.0 & 3.6 & 21.8 \\
\hline
\end{tabular}


monoxide and oxides of sulphur revealed that the engine emits more $\mathrm{CO}$ for diesel when compared to the blends. However, as the proportion of soybean oil in the blend increases the percentage of $\mathrm{CO}$ emission decreases. Also the $\mathrm{SO}_{2}$ emission for diesel and all the blends followed a decreasing trend with respect to load in all the levels.

Table 5: Exhaust gas emissions for engine run on biodiesel B15.

A) At throttle position I.

\begin{tabular}{|c|c|c|c|c|c|c|}
\hline \multirow{2}{*}{ S/No } & \multirow{2}{*}{$\begin{array}{l}\text { SPEED } \\
(\mathrm{rpm})\end{array}$} & \multirow{2}{*}{$\begin{array}{l}\text { TORQUE } \\
(\mathrm{Nm})\end{array}$} & \multirow{2}{*}{$\begin{array}{l}\text { EXHAUST } \\
\text { TEMP. }{ }^{\circ} \mathrm{C}\end{array}$} & \multicolumn{3}{|c|}{$\begin{array}{c}\text { COMPOSITION OF EXHAUST } \\
\text { TOXIC GASES (ppm) }\end{array}$} \\
\hline & & & & $\mathrm{CO}$ & $\mathrm{NO}_{2}$ & $\mathrm{SO}_{2}$ \\
\hline 1 & 2600 & 1.0 & 112 & 4 & 5.2 & 9.5 \\
\hline 2 & 2600 & 1.8 & 131 & 3 & 6.0 & 8.5 \\
\hline 3 & 2600 & 3.7 & 159 & 2.5 & 6.8 & 8.0 \\
\hline 4 & 2600 & 5.5 & 182 & 2.0 & 8.0 & 7.9 \\
\hline 5 & 2600 & 5.8 & 201 & 1.4 & 9.1 & 6.5 \\
\hline
\end{tabular}

B) At throttle position II.

\begin{tabular}{|c|c|c|c|c|c|c|}
\hline & \multirow{2}{*}{ S/No } & \multirow{2}{*}{$\begin{array}{c}\text { SPEED } \\
(\mathrm{rpm})\end{array}$} & \multirow{2}{*}{$\begin{array}{c}\text { TORQUE } \\
(\mathrm{Nm})\end{array}$} & \multirow{2}{*}{$\begin{array}{c}\text { EXHAUST } \\
\text { TEMP. }{ }^{\circ} \mathrm{C}\end{array}$} & \multicolumn{4}{|c|}{\begin{tabular}{c}
\multicolumn{4}{|c|}{ TOXITION OF EXHAUST } \\
\cline { 5 - 7 }
\end{tabular}} & & & $\mathrm{CO}$ & $\mathrm{NO}_{2}$ & $\mathrm{SO}_{2}$ \\
\hline 1 & 1900 & 0.9 & 104 & 2.5 & 4.8 & 10.4 \\
\hline 2 & 1900 & 1.1 & 111 & 2.1 & 5.2 & 9.0 \\
\hline 3 & 1900 & 2.0 & 130 & 1.8 & 5.9 & 9.2 \\
\hline 4 & 1900 & 3.4 & 143 & 1.3 & 6.3 & 8.3 \\
\hline 5 & 1900 & 3.8 & 159 & 1.0 & 6.8 & 7.0 \\
\hline
\end{tabular}

C) At throttle position III.

\begin{tabular}{|c|c|c|c|c|c|c|}
\hline \multirow{2}{*}{$\mathrm{S} / \mathrm{No}$} & \multirow{2}{*}{$\begin{array}{l}\text { SPEED } \\
(\mathrm{rpm})\end{array}$} & \multirow{2}{*}{$\begin{array}{l}\text { TORQUE } \\
(\mathrm{Nm})\end{array}$} & \multirow{2}{*}{$\begin{array}{l}\text { EXHAUST } \\
\text { TEMP. }{ }^{\circ} \mathrm{C}\end{array}$} & \multicolumn{3}{|c|}{$\begin{array}{c}\text { COMPOSITION OF EXHAUST } \\
\text { TOXIC GASES (ppm) }\end{array}$} \\
\hline & & & & $\mathrm{CO}$ & $\mathrm{NO}_{2}$ & $\mathrm{SO}_{2}$ \\
\hline 1 & 1200 & 0.7 & 90 & 1.7 & 3.4 & 9.1 \\
\hline 2 & 1200 & 1.5 & 109 & 1.4 & 3.8 & 7.1 \\
\hline 3 & 1200 & 1.9 & 123 & 1.1 & 4.1 & 6.3 \\
\hline 4 & 1200 & 2.3 & 130 & 0.9 & 4.4 & 6.5 \\
\hline 5 & 1200 & 2.6 & 139 & 0.8 & 5.6 & 5.8 \\
\hline
\end{tabular}


Table 6: Exhaust gas emissions for engine run on biodiesel B20.

A) At throttle position I.

\begin{tabular}{|c|c|c|c|c|c|c|}
\hline \multirow{2}{*}{$\mathrm{S} / \mathrm{No}$} & \multirow{2}{*}{$\begin{array}{c}\text { SPEED } \\
(\mathrm{rpm})\end{array}$} & \multirow{2}{*}{$\begin{array}{c}\text { TORQUE } \\
(\mathrm{Nm})\end{array}$} & \multirow{2}{*}{$\begin{array}{c}\text { EXHAUST } \\
\text { TEMP. }{ }^{\circ} \mathrm{C}\end{array}$} & \multicolumn{3}{|c|}{\begin{tabular}{c} 
COMPOSITION OF EXHAUST \\
\cline { 4 - 6 }
\end{tabular}} \\
\hline 1 & 2600 & 2.3 & 141 & 1.0 & 9.1 & 8.2 \\
\hline 2 & 2300 & 2.3 & 134 & 1.0 & 11.8 & 7.2 \\
\hline 3 & 1900 & 2.3 & 128 & 0.8 & 14.2 & 6.2 \\
\hline 4 & 1500 & 2.3 & 126 & 0.7 & 16 & 5.8 \\
\hline 5 & 1200 & 2.3 & 124 & 0.7 & 18.0 & 5.0 \\
\hline
\end{tabular}

B) At throttle position II.

\begin{tabular}{|c|c|c|c|c|c|c|}
\hline \multirow{2}{*}{$\mathrm{S} / \mathrm{No}$} & \multirow{2}{*}{$\begin{array}{c}\text { SPEED } \\
(\mathrm{rpm})\end{array}$} & \multirow{2}{*}{$\begin{array}{c}\text { TORQUE } \\
(\mathrm{Nm})\end{array}$} & \multirow{2}{*}{$\begin{array}{c}\text { EXHAUST } \\
\text { TEMP. }{ }^{\circ} \mathrm{C}\end{array}$} & \multicolumn{3}{|c|}{\begin{tabular}{c} 
COMPOSITION OF EXHAUST \\
\cline { 4 - 7 }
\end{tabular}} \\
\cline { 5 - 7 } & 2600 & 1.8 & 130 & 2.0 & 12.8 & 8.2 \\
\hline 2 & 2300 & 1.8 & 126 & 1.6 & 13.1 & 7.1 \\
\hline 3 & 1900 & 1.8 & 120 & 1.2 & 13.5 & 6.8 \\
\hline 4 & 1500 & 1.8 & 116 & 1.0 & 15 & 6.1 \\
\hline 5 & 1200 & 1.8 & 114 & 1.0 & 17.0 & 5.9 \\
\hline
\end{tabular}

C) At throttle position III.

\begin{tabular}{|c|c|c|c|c|c|c|}
\hline \multirow{2}{*}{ S/No } & \multirow{2}{*}{$\begin{array}{l}\text { SPEED } \\
(\mathrm{rpm})\end{array}$} & \multirow{2}{*}{$\begin{array}{l}\text { TORQUE } \\
(\mathrm{Nm})\end{array}$} & \multirow{2}{*}{$\begin{array}{l}\text { EXHAUST } \\
\text { TEMP. }{ }^{\circ} \mathrm{C}\end{array}$} & \multicolumn{3}{|c|}{$\begin{array}{c}\text { COMPOSITION OF EXHAUST } \\
\text { TOXIC GASES (ppm) }\end{array}$} \\
\hline & & & & $\mathrm{CO}$ & $\mathrm{NO}_{2}$ & $\mathrm{SO}_{2}$ \\
\hline 1 & 2600 & 0.8 & 107 & 3.2 & 10.6 & 9.3 \\
\hline 2 & 2300 & 0.8 & 102 & 3.0 & 10.9 & 9.1 \\
\hline 3 & 1900 & 0.8 & 94 & 2.9 & 11.3 & 8.8 \\
\hline 4 & 1500 & 1.8 & 91 & 2.9 & 13 & 8.4 \\
\hline 5 & 1200 & 0.8 & 88 & 3.1 & 16.6 & 7.9 \\
\hline
\end{tabular}


Table 7: Sample regression analysis of experimental results.

\begin{tabular}{|c|c|c|c|c|c|c|}
\hline \multicolumn{2}{|c|}{ Regression Statistics } & & & & & \\
\hline Multiple R & 0.804328 & & & & & \\
\hline R Square & 0.646944 & & & & & \\
\hline $\begin{array}{l}\text { Adjusted R } \\
\text { Square }\end{array}$ & 0.619348 & & & & & \\
\hline $\begin{array}{l}\text { Standard } \\
\text { Error }\end{array}$ & 1.310807 & & & & & \\
\hline Observations & 120 & & & & & \\
\hline \multirow[t]{2}{*}{ ANOVA } & & & & & & \\
\hline & $d f$ & $S S$ & $M S$ & $F$ & $\begin{array}{c}\text { Significance } \\
F \\
\end{array}$ & \\
\hline Regression & 7 & 355.7777 & 50.82539 & 34.51042 & $3.3 \mathrm{E}-25$ & \\
\hline Residual & 113 & 194.1582 & 1.718214 & & & \\
\hline \multirow[t]{2}{*}{ Total } & 120 & 549.9359 & & & & \\
\hline & Coefficients & $\begin{array}{l}\text { Standard } \\
\text { Error }\end{array}$ & t Stat & P-value & Lower 95\% & $\begin{array}{c}\text { Upper } \\
95 \%\end{array}$ \\
\hline Intercept & 1428.649 & 2128.358 & 0.671244 & 0.503435 & -2788.01 & 5645.31 \\
\hline SPEED & 0.001571 & 0.00026 & 6.041589 & $2 \mathrm{E}-08$ & 0.001056 & 0.002087 \\
\hline TORQUE & -0.24845 & 0.115643 & -2.14841 & 0.033816 & -0.47756 & -0.01934 \\
\hline THTR & -2.46701 & 0.770803 & -3.20057 & 0.001781 & -3.99411 & -0.93991 \\
\hline $\mathrm{C}$ & -1634.59 & 2434.425 & -0.67145 & 0.503306 & -6457.62 & 3188.446 \\
\hline $\mathrm{H}$ & 0 & 0 & 65535 & \#NUM! & 0 & 0 \\
\hline $\mathrm{O}$ & -1419.82 & 2190.505 & -0.64817 & 0.51819 & -5759.6 & 2919.966 \\
\hline S & -1258.72 & 2273.634 & -0.55362 & 0.580935 & -5763.2 & 3245.758 \\
\hline
\end{tabular}

The exhaust emission of sulphur dioxide from biodiesel blends is observed to be about $40 \%$ lower than the sulphur dioxide emission from diesel. Statistical analysis of the results shows that correlation coefficients (R-square) of about $93 \%$ and $96 \%$ which signifies that there is a good relationship between the observed and predicted $\mathrm{NO}_{2}$ and $\mathrm{SO}_{2}$ emissions respectively. The low value of about $65 \%$ correlation for $\mathrm{CO}$ emission might be due to experimental errors (Table 7). The key findings are the predictive model equations for the emission of $\mathrm{NO}_{2}, \mathrm{CO}$ and $\mathrm{SO}_{2}$ respectively with respect to engine speed (n), torque (T), throttle position $(\mathrm{Z})$ and the elemental compositions $(\mathrm{C}, \mathrm{O}$ and $\mathrm{S})$ for the liquid fuel blends used in the study: 


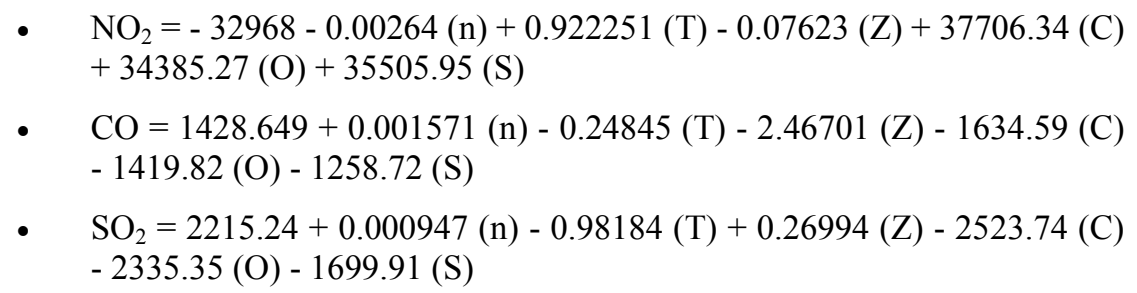

\section{Conclusion}

This study has investigated the effects of fuel composition and operating regime of a low speed direct injection engine on its emission characteristics. The key findings are the predictive model equations for the emission of $\mathrm{NO}_{2}, \mathrm{CO}$ and $\mathrm{SO}_{2}$ respectively as functions of the engine speed $(\mathrm{n})$, torque $(\mathrm{T})$, throttle position $(\mathrm{Z})$ and the elemental compositions $(\mathrm{C}, \mathrm{O}$ and $\mathrm{S})$ for the liquid fuel blends used in the study.

The concentration of hydrogen in the fuel does not have any effect on the predictive equations because when included in the regression analysis, the coefficient is always zero. From the environmental point of view, the B15 fuel was established to be a good alternative to diesel fuel because the study revealed that there were low $\mathrm{NO}_{2}, \mathrm{CO}$ and $\mathrm{SO}_{2}$ emissions for this blend as compared to other fuel blends used in the study. The results show that engine run on B15 gives lowest Nitrogen dioxide $\left(\mathrm{NO}_{2}\right)$ emission of $2.58 \mathrm{ppm}$, carbon monoxide (CO) emission of $0.153 \mathrm{ppm}$ and sulphur dioxide $\left(\mathrm{SO}_{2}\right)$ emission of $6.5 \mathrm{ppm}$ when compared to other fuel blends. The observed increase in $\mathrm{NO}_{2}$ emissions of the all the biodiesel blends as compared to B0 (petro diesel) is in agreement with Canakci [6].

\section{References}

[1] Kegl, B. Effects of biodiesel on emissions of a bus diesel engine. Bioresource Technology, 99, pp. 863-73, 2008.

[2] Lin, C.Y. \& Pan, J.Y. The effects of sodium sulphate on the emissions characteristics of an emulsified marine diesel oil-fired furnace. Ocean Eng. 28(4), pp. 347-360, 2001.

[3] Lin, C.Y. Influences of vanadium compound on burning characteristics of emulsified fuel oil C. Ocean Eng., 27(6), pp. 589-601, 2000.

[4] Linak, W.P. \& Wendt, J.O.L. Toxic metal emissions from incineration: mechanism and control. Prog. Energy Combust. Sci. 19, pp. 145-185, 1993.

[5] Ken, B. How to Do a Multiple Regression in Excel 2007, 2012.

[6] Canakci, M. Performance and emissions characteristics of biodiesel from soybean oil. Proceedings of the Institution of Mechanical Engineers, Part D: Journal of Automobile Engineering Vol. 219: 915-922, 2005, DOI: $10.1243 / 095440705 \times 28736$. 